\title{
Albrecht Dürer and the Ideal City
}

\author{
Tessa Morrison
}

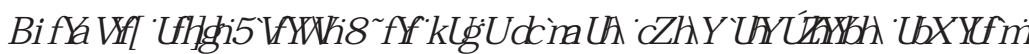
sixteenth centuries. He is generally known as a painter, engraver, printmaker, mathematician, and art theorist; architect, social reformer, and utopian writer are not in the normal list of his achievements. In 1527, Dürer published Etliche Unterricht, zur Befestigung der Städte, Schlösser und Flecken (Instruction

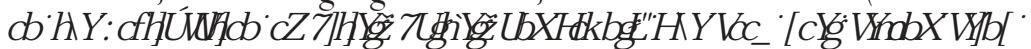

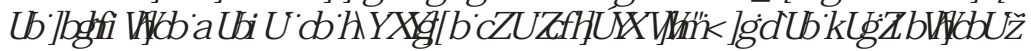
pragmatic, and socially responsible, and the purpose of its design was to improve the status and lifestyle of German artisans. Dürer's ideal city was not an isolated work; it was compatible with his other writings that were directed towards the improvement of artisans' skills and conditions.
\end{abstract}

\section{Background}

In post-medieval Europe, there was a revolution in art and the emergence of distinct cultural identities. France had created the Gothic style and Italy was the hub of the Renaissance which saw a profusion of discovery and the development of new ideas based on classical ideals. The Germany that Albrecht Dürer was born into, in 1471, had not developed or practised any universal 'German' style of art: 'The Germans, so easily regimented in political and military life, were prone to extreme subjectivity and individualism in religion, in metaphysical thought and, above all, in art.' ${ }^{1}$ Nevertheless, it was also a time of change that reflected a spirit of revival of Germanic patriotism that drew upon ancient German history and surviving classical authors, in particular the Roman historian Tacitus. This sense of renewal became a widespread scholarly movement. ${ }^{2}$

In Dürer's lifetime, Nuremberg was the centre of German humanism. Although Dürer had an elementary education he counted among his personal friends Germany's leading humanists, such as his closest friend and confidant, Willibald Pirckheimer who was one of Germany's most influential humanists and a prolific translator of essential ancient texts by Xenophon, Lucian, Isocrates, Plutarch, and Plato from Greek into Latin and German.

${ }^{1}$ Erwin Panofsky, Albrecht Dürer (Princeton, NJ: Princeton University Press, 1943), p. 3.

${ }^{2}$ Larry Silver, 'Germanic Patriotism in the Age of Dürer', in Dürer and His Culture, eds Dagmar Eichberger and Charles Zika (Cambridge: Cambridge University Press, 1998), pp. $38-68$. 
He strove to cultivate the study of humanity and utopian ideals in Germany. Pirckheimer's translations were influential and had universal appeal with international scholars and he had a close relationship with Erasmus with whom he corresponded. ${ }^{3}$ The Swiss edition of Thomas More's Utopia published in 1518 , possibly under the auspices of Erasmus, was dedicated to Pirckheimer. ${ }^{4}$

The humanist circle that Dürer frequented included some of the greatest German minds of the time such as Konrad Celtis, poet Laureate and often dubbed the 'arch humanist'; the Augsburg humanist and diplomat Konrad Peutinger, who allowed all interested people access to his extensive library, including Dürer; the classicist Konrad Peutinger; the theologian-poet Johann Cochläus; the astronomer Niklas Kratzer who met Dürer at Erasmus's house in the Netherlands; Benedictus Chelidonius, the author of the Latin poetry that served as a text to Dürer's Marienleban; and Beatus Rhenanus who was known as Erasmus's 'alter ego' ${ }^{5}$ All were personal friends of Dürer, as were many other humanists, reformers, and artists. This humanist circle of friends exposed Dürer to literature covering the ideals of the Italian Renaissance and the ancient world and exerted a great deal of influence on a man who wanted to find out everything connected to art, its origins, its developmental stages, its styles and importantly, how this knowledge could be passed on to others, and in particular, to young German artists. ${ }^{6}$

Dürer's reputation as an artist during his lifetime was widespread and he not only promoted his own work but also promoted the work of his students and other artists. ${ }^{7}$ Dürer published three books: Underweysung der Messung mit dem Zirckel und Richtscheyt (Instructions for Measuring with Compass and Ruler) was first published in $1525 ;^{8}$ Etliche Unterricht, zur Befestigung der Städte, Schlösser und Flecken (Instruction on the Fortification of Cities, Castles, and Towns) in 1527; ${ }^{9}$ and Vier Bücher von Menschlicher Proportion (Four Books

\footnotetext{
${ }^{3}$ Hanan Yoran, Between Utopia and Dystopia: Erasmus, Thomas More and the Humanist Republic of Letters (Plymouth: Lexington, 2010), p. 66.

${ }^{4}$ Jane Campbell Hutchison, Albrecht Dürer: A Biography (Princeton, NJ: Princeton University Press, 1990), p. 49.

${ }^{5}$ Jane Campbell Hutchison, Albrecht Dürer: A Guide to Research (New York and London: Garland, 1999), pp. 1-2.

${ }^{6}$ Peter Strieder, The Hidden Dürer, trans. Vivienne Menkes (Milan: Arnoldo Mondadori Editore, 1976), p. 12.

${ }^{7}$ Marcel Brion, Albrecht Dürer: His Life and Work (London: Thames and Hudson, 1960), p. 236.

${ }^{8}$ Albrecht Dürer, Underweysung Der Messung, in De symmetria partium in rectis formis humanorum corporum (Nuremberg, 1532); Underweysung der Messung (Nuremberg, 1538), ed. David Price (Oakland, CA: Octavo, 2003) (digitised facscimile).

${ }^{9}$ Albrecht Dürer, Etliche Unterricht, Zur Befestigung der Städte, Schlösser und Flecken (Nuremberg, 1527).
}

Parergon 31.1 (2014) 
on Human Proportion) was published posthumously in October $1528 .^{10} \mathrm{He}$ also worked on a book entitled Speiss für Malerknaben (Food for the Young Painter) but only the introduction survives in manuscript form. ${ }^{11}$ These instruction manuals were originally written in German and later editions, after Dürer's death, were translated and published in Latin. Dürer strove to reveal the 'secret' of his art and in particular he was concerned with the art of perspective.

The art of perspective was a guarded secret held by mathematicians who practised art such as Andrea Mantegna, Paolo Uccello, and Piero della Francesca. Francesca wrote a manuscript entitled De Prospectiva Pingendi (On the Perspective for Painting) ${ }^{12}$ which revealed the art of perspective, but it remained in manuscript form until 1899. Although he may have known of its existence, this manuscript was not available to Dürer. In Dürer's first visit to Venice in 1505, he pursued all knowledge of painting, including the art of perspective. At the end of this stay in Venice in 1506, Dürer wrote to his friend Pirckheimer of his planned return journey home to Nuremberg and stated 'I should like to travel to Bologna to learn the secrets of the art of perspective, which a man there is willing to teach me. I should stay there about eight or ten days and then come back to Venice'. ${ }^{13}$ Through Christoph Scheurl's Life of Anton Kress published in 1515, it is known that Dürer did accomplish his intention to visit Bologna. ${ }^{14}$ There remains speculation as to who instructed him in the art of perspective but it is thought to have been the mathematician Luca Pacioli. ${ }^{15} \mathrm{He}$ ended the letter with an insightful comment on the respective status of artists in Italy and Germany, stating 'Here (in Venice) I am a gentleman, at home a parasite' ${ }^{16}$

Dürer wanted to foster German artists and to improve their status in German society. In the preface to Underweysung der Messung, he claimed

It has until now been the custom in our Germany to put a great number of talented young men to the task of artistic painting without real foundation

${ }^{10}$ Albrecht Dürer, De Symmetria Partium in Rectis Formis Humanorum Corporum, in De symmetria partium in rectis formis humanorum corporum (Nuremberg, 1532); Underweysung der Messung (Nuremberg, 1538), ed. Price.

${ }^{11}$ London, British Library (hereafter BL), MS Sloane 5230.

12 Piero Della Francesca, De Prospectiva Pingendi (Sansepolcro: Aboca Edizioni, 2009).

${ }^{13}$ Albrecht Dürer, Memoirs of Journeys to Venice and the Low Countries, trans. Roger Eliot Fry (Boston: Merrymount, 1913), p. 27.

${ }^{14}$ William Conway, Literary Remains of Albrecht Dürer (Cambridge: Cambridge University Press, 1899), p. 58.

15 Strieder, Hidden Dürer, p. 17.

${ }^{16}$ Dürer, Memoirs of Journeys, p. 27. 
other than what they learned by daily usage. They have therefore grown up in ignorance like an unpruned tree. ${ }^{17}$

The foundation to all painting, according to Dürer, was geometry: 'I have decided to provide to all those who are eager to become artists a starting point and a source for learning about measurement with rulers and compass. ${ }^{18}$ In Underweysung der Messung there are four books. Book One begins with Euclid's definitions of point, line, surface, and solid, and is primarily concerned with linear geometry. In Book Two, he describes triangles, rectangles, and regular polygons. Book Three begins the treatment of solids, but is devoted predominantly to practical applications of these solids. It then gives an interesting dissertation on architectural styles of columns, and techniques for constructing different types of sundials. Book Four contains an analysis of the properties of the polyhedra, and the book concludes with a detailed description of the art of perspective and its practical use for artists.

Dürer made an extensive study of the construction of the human body. He observed that:

Vitruvius, the ancient architect, whom the Romans employed upon great buildings, says, that whosoever desires to build should study the perfection of the human figure, for in it are discovered the most secret mysteries of Proportion. So, before I say anything about Architecture, I will state how a well-formed man should be made, and then about a woman, a child, and a horse. Any object may be proportioned out (literally, measured) in a similar way. ${ }^{19}$

Despite this, he did not adopt the proportions of the Vitruvian man as his model. Dürer had met with the Italian artist Jacopo de Barbari who showed him proportional studies of a man and a woman; however,

I realised that Jacopo would not clearly explain his principles. So I set to work on my own and read Vitruvius, who writes a little about a man's limbs. Thus I took my start from or out of [the work of] these two men, and since then have continued my search from day to day according to my own notions. ${ }^{20}$

Dürer's system was a comprehensive study of years of his own theory founded on empirical testing which he later published as Vier Bücher von Menschlicher Proportion. This study may have begun well before he arrived in Venice in 1505.

${ }^{17}$ Dürer, Underweysung Der Messung, sig. A $1^{v}$. Unless, otherwise noted, translations are the author's own.

${ }^{18}$ Dürer, Underweysung Der Messung, sig. A $1^{\mathrm{v}}$.

${ }^{19}$ Conway, p. 165, quoting Dürer.

${ }^{20}$ Conway, p. 165, quoting Dürer. 
Proportional studies of figures of Dürer's have been dated as early as $1500 .^{21}$ Thus these two significant books were as a result of twenty to twenty-five years' research before they were published in 1525 and 1528 respectively. Presumably his unfinished work Speiss für Malerknaben, which is dated 1512, ${ }^{22}$ was a beginning draft of these two works.

Dürer bought copies of Euclid and Vitruvius, written in Latin, on his first trip to Venice. His Latin was poor but he was able to get help from his friends in the humanist circle in which he moved. Both Pirckheimer and Kratzer wrote out passages in German translation for him. ${ }^{23}$ He used the writings of Vitruvius and Euclid in his search for aesthetic perfection in art and architecture. On his travels from Antwerp to Aachen in 1520 he noted in his diary that pillars, which he believed were bought to Aachen from Rome by Charlemagne, were well proportioned and that 'these are made truly according to Vitruvius' writing'. ${ }^{24}$ While Dürer developed his own system for the artistic construction of the human proportions and a measure of aesthetics, he agreed with the Vitruvian proportions as a measure of architectural aesthetics. He claimed

I believe that it is no secret to any famous architect or workman how skilfully and masterfully the ancient Roman Vitruvius has written about the durability, usefulness, and ornamentation of buildings. For these reasons his teachings should be followed in preference to those of others. ${ }^{25}$

He qualifies this statement by claiming that German taste should be taken into consideration, although, he did favour the classical roof with a slope of no more than 20 degrees against the steep Gothic ones that were popular in Germany, thus rejecting what was considered as German taste. ${ }^{26}$

Dürer's work had an impact on subsequent scholarship. Kepler and Galileo quoted from Underweysung der Messung. ${ }^{27}$ Architectural theorist Daniele Barbari praises Dürer's book on geometry 'which contains very useful and beautiful practices'. ${ }^{28}$ He also copied Dürer's images that demonstrated the

${ }^{21}$ Eckhard Schaar, 'A Newly Discovered Proportional Study by Dürer in Hamburg', Master Drawings, 36 (1998), 59-66 (p. 63).

${ }^{22}$ BL, MS Sloane 5230; for dating, see Hutchison, Biography, p. 111.

${ }^{23}$ Brion, His Life and Work, pp. 191, 205; and Panofsky, Albrecht Dürer, p. 257.

${ }^{24}$ Dürer, Memoirs of Journeys, p. 56.

${ }^{25}$ Dürer, Underweysung Der Messung, sig. G4r.

${ }^{26}$ BL, MS Sloane 5229, pp. 165-66.

${ }^{27}$ Panofsky, p. 270.

${ }^{28}$ Margaret Muther D’Evelyn, Venice and Vitruvius (New Haven, CT: Yale University Press, 2012), p. 110. 
art of perspective in his publication on Vitruvius. ${ }^{29}$ These two books on the proportions of the human body and measurements were extremely popular and useful tools for many artists. They were directed and written for the artist's development.

Etliche Unterricht is a comprehensive manual written to instruct a powerful ruler on building and improving the fortifications of a city, and it is dedicated to Ferdinand I, King of Hungary and Bohemia (the future Holy Roman Emperor). As in his other work, Dürer utilised the geometry of Euclid and the architectural theory of Vitruvius as the basis of his own theories and design on military architecture. His investigations in geometry, human proportions, and architecture were all part of the working out of a single idea, that of measurement and proportion: for Dürer these were the basis of all art. Many biographies of Dürer do not even mention this work on fortification, or if it is mentioned, they deal with it dismissively in one or two sentences. ${ }^{30}$ Military historians have also passed over his work, ${ }^{31}$ because the German round bastions and tower that Dürer favoured were being superseded by the newly invented angular bastions designed by Italian military engineers. ${ }^{32}$ In both of these cases, his work on fortifications is treated as if it is an isolated work that has no bearing on any other of his writings. Consequently this book is a neglected one. Yet, it is an important work and is directly related to his other studies.

\section{Instruction on the Fortification of Cities, Castles, and Towns}

Books and manuscripts that included sections on fortifications had begun to

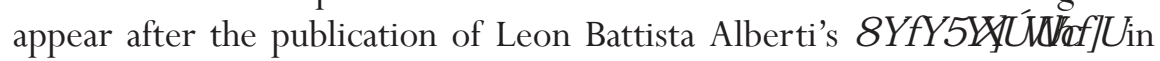
1485. Architectural theorists such as Antonio Averlino (known as Filarete) and Francesco di Giorgio had included fortifications in their theses on architecture. Niccolò Machiavelli published The Art of War in 1512, but he was

${ }^{29}$ Kirsti Andersen, The Geometry of an Art: The History of Mathematical Theory of Perspective from Alberti to Monge (Copenhagen: Springer, 2007), p. 155.

${ }^{30}$ See, for example, Panofsky, Albrecht Dürer, p. 272; Strieder, Hidden Dürer; Gerald Strauss, Nuremberg in the Sixteenth Century (New York: John Wiley \& Son, 1966).

${ }^{31}$ Giovanni Maria Fara, Albrecht Dürer Teorico Dell'architettura: Una Storia Italiana (Florence: Olschki, 1999), p. 46.

${ }^{32}$ Christopher Duffy, Siege Warfare: The Fortress in the Early Modern World 1494-1660 (London: Routledge \& Kegan Paul, 1979); J. R. Hale, 'The Early Development of the Bastion: An Italian Chronology c. 1450-c. 1534', in Europe in the Late Middle Ages, eds J. R. Hale, J. R. L. Highfield, and B. Smalley (London: Faber and Faber, 1965), pp. 466-94; Simon

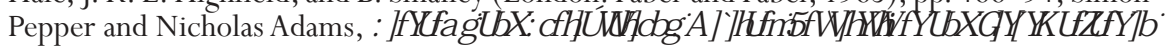
Sixteenth-Century Siena (Chicago: University of Chicago Press, 1986).

Parergon 31.1 (2014) 
against the dependence on fortified cities and in favour of a citizen's army. ${ }^{33}$ The science of fortification was a branch of mathematics and art, and artists such as Leonardo daVinci and Michelangelo discussed fortified cities, but these were largely in the form of fragmentary sketches and notes. ${ }^{34}$ Albrecht Dürer was well suited to developing fortifications based on geometrical principles.

Etliche Unterricht consists of four main sections: the construction of bastions, which Dürer defined as three different designs of semicircular bastions; the construction of an ideal city around a fortified residence of the powerful ruler; a description of the circular fortress which would protect the borders of the ruler's lands; and strengthening the fortifications of an existing city. It was first published in Nuremberg in 1527 and was written in German, and there were several later editions, notably a Latin edition published in Paris in 1537 entitled De urbibus arcibus Castellisqe Codendis. Although its publication had little impact in Italy, it was influential in Germany, and particularly in the Protestant territories. ${ }^{35}$ Dürer's scheme had multi-tiers of gun emplacements in massive semicircular towers flanked by isolated casements in the ditches. The multi-levelled gun tower was possibly the most common early northern European contribution to city fortifications, particularly in Germany and Poland. ${ }^{36}$

While tradition has it that Dürer fortified the town of Nuremberg, ${ }^{37}$ the fortifications around Nuremberg were not erected until ten years after Dürer's death. It is claimed that these fortifications and bastions were very similar to Dürer's description in Etliche Unterricht ${ }^{38}$ and thus it is possible that they were constructed to his plans.

In England, by the 1530s, Henry VIII had many old castles that had fallen into disrepair and after Henry broke with the Pope he expected an invasion from Catholic Europe. He decided to build a line of forts on the south coast designed for artillery and equipped with the latest types of guns. Examples

${ }^{33}$ Niccolò Machiavelli, The Art of War, ed. and trans. Christopher Lynch (Chicago: University of Chicago Press, 2003).

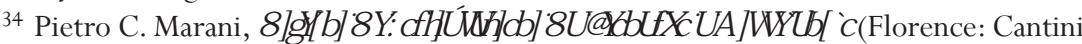
Edizioni d'Art, 1984); Pietro C. Marani, 'Leonardo: Fortified Architecture and Its Structural Problems', in Leonardo DaVinci: Engineer and Architect, ed. Paolo Galluzzi (Quebec: Montreal Museum of Fine Arts, 1987), pp. 303-14; Kim Williams, 'Leonardo Da Vinci's Military Architecture', in Festungsbau: Geometrie, Technologie, Sublimierung, eds Bettina Marten, Ulrich Reinisch, and Michael Korey (Berlin: Lukas Verlag, 2012), pp. 107-18.

${ }^{35}$ Michael J. Lewis, 'Utopia and the Well-Ordered Fortress: J. M. Von Schwalbach's Town Plans of 1635', Architectural History, 37 (1994), 24-36 (p. 28).

${ }^{36}$ Pepper and Adams, p. 22.

${ }^{37}$ M. Macdermott, An Essay on Military Architecture of the Middle Ages (Westport, CT: Greenwood, 1977).

${ }^{38}$ Mrs Charles W. Heaton, A History of the Life of Albrecht Dürer of Nürnberg (London: Macmillan, 1870), p. 24. 
still exist of these forts at Sandown, Walmer, and Deal in Kent, Camber in Sussex, and St Mawes and Pendennis in Cornwall. ${ }^{39}$ These fortifications show strong parallels with the work of Dürer. There are semicircular bastions, a heavy reliance on smoke vents, and there is a strong similarity in the overall design. Dürer developed traditional forms of military architecture and the similarity could be coincidental; however, Henry VIII engaged a German engineer named Stefan von Haschenparg ${ }^{40}$ who would have been familiar with Dürer's work.

One of the stimuluses for this book may have occurred when, in 152021, Dürer's advice was sought on the defences of Antwerp. ${ }^{41}$ There were rapid developments in military engineering and architecture in the Renaissance and for many artists between 1450 and 1550 military design was not only a major source of income, it was a major preoccupation. ${ }^{42}$ Etliche Unterricht is more than a manual for fortifications: a significant portion of the book discusses the building of the ideal city. Stimulus for this may have come with the building of Fuggerei, an ideal social settlement within the city of Augsburg ${ }^{43}$ built by Jacob Fugger, nicknamed 'the rich', a wealthy banking merchant and patron of the arts, and of Dürer.

The housing shortage for the poor was critical in Germany in the early sixteenth century. Fugger had established a benevolent fund for the poor in 1511 of 15,000 guldens and in 1518 he founded a charity to help poor labourers and craftsmen by not only building an enclosed settlement for them but also providing for the buildings' maintenance. His last will, dated $1521,{ }^{44}$ combined these two funds into a foundation that built and continued to maintain this settlement.

Originally the land was just outside town, it was a walled settlement with seven gates that were shut in the evening. It consisted of six streets, 53 houses, each of which contained two flats and it also had its own church with large gardens and open spaces (see Figure 1). ${ }^{45}$ The original plans record the settlement's builder as one Thomas Krebs, but nothing more is known of this man. The settlement, which became known as the Fuggerei, was built for the

${ }^{39}$ B. H. O'Neil, Castles and Cannon (Oxford: Clarendon Press, 1960), p. 61; Peter Harrington, The Castles of Henry VIII (Oxford: Osprey, 2007).

${ }^{40}$ Harrington, p. 13.

${ }^{41}$ O’Neil, p. 63.

42 James S. Ackerman, The Michelangelo of Architecture (London: Zwemmer, 1966), p. 45.

${ }^{43}$ Jacob Strieder, Jacob Fugger the Rich, Merchant and Banker of Augsburg, 1459-1525 (Hamden, CT: Archon, 1966), pp. 174-76.

${ }^{44}$ B. Ann Tlusty, Augsburg During the Reformation Era (Indianapolis: Hackett, 2012), p. 80.

${ }^{45}$ Marion Tietz-Strodel, Die Fuggerei in Augsburg: Studien zur Entwicklung des sozialen Stiftungsbaus im 15. und 16. Jahrhundert (Tubingen: Mohr, 1982). 
labourers and craftsmen of Augsburg. The requirements for admission to it were citizenship, being of the Catholic faith, married, respectable, and poor. ${ }^{46}$

The plot of land for the settlement was originally rectangular; however, it was expanded within only a few years of its completion making it a nonsymmetrical shape. There was an overall order and plan that were very typical to many cities throughout Germany with the houses being fitted to the topology of the land. The housing estate and its walls still exist and it is a famous tourist destination of Augsburg. It is also the oldest social housing scheme in the world. The original houses were similar in architecture, emphasising the egalitarian nature of the settlement. They had classic Gothic roofs and were light and airy, with a good water supply and drainage. ${ }^{47}$ These were ideal living conditions within the safety of the enclosed walls. The rent for these houses was minimal at one Rhein Guilder (about \$1.25) per year which would not have paid for the upkeep of the building. This was supplied by the charitable fund set up by Fugger, which continues to renovate and maintain Fuggerei today. The rents have remained unchanged since the sixteenth century. ${ }^{48}$ It is considered that Fugger used Thomas More's Utopia published in 1516 as the model for the plan behind the design of the estate. ${ }^{49}$ Fugger and More were both in Antwerp in 1515 and Fugger was aware of Utopia before its publication. ${ }^{50}$ Fugger emulated the design and the benevolent principles of More, but not the underlying political philosophy.

Dürer had a close relationship with Augsburg and the Fugger family. Dürer had been a friend and was patronised by the Fugger family for many years. Gastel Fugger was a friend of both Dürer and Pirckheimer and travelled between Nuremberg and Venice in $1506 .{ }^{51}$ While in Venice, Dürer was commissioned to paint a new altarpiece for the chapel of the German merchants, and one of the principal donors was the Fugger family. ${ }^{52}$ Dürer created drawings of Jacob's older brother Ulrich in 1510 and painted Jacob Fugger's portrait, executing the life drawing when they met at the Imperial

${ }^{46}$ Ludwig Waagen, 'Golden Augsburg and Its Fuggerei', American-German Review, 2 (1936), 22-27 (p. 23).

${ }^{47}$ Tietz-Strodel, p. 95.

${ }^{48}$ Mike Esterl, 'In This Picturesque Village, the Rent Hasn't Been Raised since 1520', Wall Street Journal, Friday, 26 December 2008.

${ }^{49}$ Tietz-Strodel, p. 234

${ }^{50}$ Tietz-Strodel, p. 227.

${ }^{51}$ Mark Haberlein, The Fuggers of Augsburg: Pursuing Wealth and Honour in Renaissance Germany (Charlottesville: University of Virginia Press, 2012), p. 128. In a letter dated 7 February 1506, Dürer, writing to Pirckheimer, stated 'I also specially charged Castel (Fugger) to convey my service to you'; Gastel's name is repeatedly misspelt in reproductions of Dürer's letters. See Dürer, Memoirs of Journeys, p. 5.

${ }^{52}$ Conway, Literary Remains, p. 45. 
Diet in Augsburg in 1518..$^{53}$ Jacob also commissioned Dürer to design his tomb; the tomb was executed in the style of Dürer, but was not executed by Dürer. At the same time the Fuggers earned a lot of money from the sale of Dürer's artwork. Their trading posts, which were located throughout Europe, handled the sale of the Nuremberg artist's engravings. It is said that Dürer gave advice to the Fuggers during the construction of Fuggerei, ${ }^{54}$ however, the extent of this advice is unknown.

Raising the living conditions and status of the German artisans was a topic that was close to Dürer's heart and in Etliche Unterricht he designed a city that would help improve the conditions and status of the artisans. Although it was more comprehensive in its design and larger in its scope than Fuggerei and its design was distinctly different, there is a strong similarity in the underlying philosophy of the cities - which was to raise conditions and to enhance the skill of the artisans and craftsmen of Germany.

\section{Description of Dürer's Ideal City}

Dürer's city with its fortifications is a square of 4,300 feet with the corners truncated through a line of 600 feet. A significant proportion of this area is dedicated to the fortifications and ditches that protect the city (see Figure 2). The city itself surrounds the Royal precinct, which is a square of 1,012 feet, and is surrounded by a high wall and ditch which Dürer refers to as the King's Ditch. The city that surrounds it is a square of 2,212 feet (see Figure 3). However, the city is not for everyone to live in: 'The Lord shall not allow useless people to live in this Fortress, but talented, high, wise, manly, experienced, skilful men, good tradesmen who are capable with respect to fortifications, rifle makers and good marksmen. ${ }^{55}$

The corners of the city are aligned to face the four winds. In Figure 3, the letter A designates the east corner, B the west, C the south, and D the north. The arrangement of the subdivisions of the city accommodates and complements the different groups and trades within the city. The city is divided into a grid of sixteen squares and each one of these squares has its own system of subdivision depending on its use. Figure 3 also shows Dürer's arrangement of the buildings within the city. The arrangement is hierarchical and the trades are conveniently placed next door to complementary trades for utility, convenience, and pollution prevention within the city.

\footnotetext{
${ }^{53}$ Hutchison, Biography, p. 84.

${ }^{54}$ Kluger, Fugger Dynasty, p. 15.

${ }^{55}$ Dürer, Etliche Unterricht, sig. Diii.
} 
In corner A, buildings 1 to 7 constitute the city's religious sector, being the church, the choir, the bell tower, sacristy, Presbytery, an enclosed garden, and accommodation for the priest. Buildings 19, 20, and 21, which surround the religious sector, are domestic buildings for people who live a quiet life by virtue of their trade. Unfortunately, Dürer does not say which trades these are. In corner C, buildings 8, 9, 10, and 11 are the casting works and they are placed in the southern corner since they must be located there 'due to the winds, as the North and West winds that blow for most of the year and also the East wind will drive the poisonous smoke away from the town and the rare south wind will blow it town ward'. ${ }^{56}$ Surrounding the casting works are buildings to house the coppersmiths, moulders, turners, smiths, and all of the tradespeople that were required for the works and their production $(22,23$, $24,25)$. In between the religious sector and the casting works is the only gate into the city and it is here that the civic buildings (13), the market (12), the stately homes $(\mathrm{X})$, and the homes for nobles $(17,18)$ are located. Buildings 15 and 16, which are next to the gate, are reserved for the captains, standard bearers, sergeants, and the most distinguished fighting men so that they can protect the gate and be equipped to go out at all times.

On the southwest side and beside the casting works are two armouries $(26,30)$ and behind the other domestic buildings are buildings 28 and 32, bath houses, for females (F) and males (M). On the western corner are the timber works (34) with six buildings for the timber workers (35). In corner $\mathrm{D}$ is the storehouse (52) which is heavily vaulted and has a cellar along its full length: 'Lard, salt, dried meat and all types of food are to be stored in this structure and corn, oats, barley, wheat, millet, fees, lentils, and similar are to be heaped in lofts under the roof. ${ }^{57}$

Between the timber works and the storehouse are structures that house the artisans. The outside of building 36 contains the wagon makers, while on the other side are the saddlers. Building 37 contains bridle makers on one side and armourers on the other. Building 38 houses the spur makers and the weapon smiths. On one side of 39, the buildings are much larger and these are for the carpenters who need long buildings for their planks of timber, while the horn turners are located on the other side. One side of building 43 is for furriers and the other contains the leather workers. Building 42 houses rope makers and tailors. The shoemakers occupy building 47, while building 46 contains small merchants and flax weavers, cloth workers, and tent makers. Buildings 40, 41, 44, and 45 are reserved for the king's visitors. These buildings have fabricated walls and rooms can be made larger or

\footnotetext{
${ }^{56}$ Dürer, Etliche Unterricht, sig. Dv.

${ }^{57}$ Dürer, Etliche Unterricht, sig. Dviii.
} 
smaller when required. Building 48 is designated for the king's goldsmiths, artists, sculptors, embroiderers, and stone masons. Building 49 contains pewterers with jewellers, needle makers, and similar metal workers. The fitters, jousting and tilting armour makers, and finishers of all things used by the nobles in jest and earnest are to be placed on one side of building 50 and on the other side, the tinsmiths, boilermakers, and embossers. Building 51 is for the loud armourers and helm smiths.

The nor theast side between the religious sector and the storehouse is the food sector. Buildings 55 and 59 are where meat is sold. The slaughterhouse for the butchers is located outside of the fortress. The bakers are housed opposite the butchers in buildings 57 and 58 and the brewers are housed in buildings 59 and 60. There are twelve inns which serve wine and they are located on the corners of buildings 29, 33, 40, 45, 53, and 54 facing the King's Ditch. Dürer's description continues:

All other people who are required and are not yet named and do not need very much space for their trade can be located in the remaining houses, in particular the most magnificent next to the king's palace. All those living on the King's Ditch shall build stalls under their houses and leave all the vaults to the traders. The businesses of the richest, such as the money changers, gold and silver, spices, silk, etc. traders, as well as a distinguished apothecary shall have the best vaults on the King's Ditch. Then, the other stall holders, who offer all kinds of smallgoods, are to be divided up and given smaller vaults than those required by the fine goods, and placed in lesser locations. The barbers shall be distributed on all four sides equally. One of the bakery stalls is to be located behind the Town Hall opposite No. 19 and the other behind Structure X, facing No. 22. ${ }^{58}$

The houses of the artisans were designed to have a workshop on the ground floor and living quarters upstairs. One of the important aspects of Fuggerei was that it provided housing for the craftsmen who otherwise would not have been able to work near their trade. In Nuremberg, there were no guilds and no chartered corporations of craftsmen who would be privileged and who could put pressure on the municipal authorities and play a political role within the city. ${ }^{59}$ The guilds in Nuremberg had been suppressed in the fourteenth century after an uprising and although the Nuremberg masters had repeatedly attempted to reinstate the guilds, the Council always turned them down. The council wrote the rules for the workshops and insured that these rules were obeyed, with harsh penalties for masters of workshops who

\footnotetext{
${ }^{58}$ Dürer, Etliche Unterricht, sig. Ei.

${ }^{59}$ Strauss, Nuremberg, p. 97; Jeffrey Chipps Smith, Nuremberg: Renaissance City, 1500 1618 (Austin: University of Texas Press, 1983), p. 46.
} 
did not obey. ${ }^{60}$ However, the council did not provide the important secondary role of the guilds which included supplying the artisans with assistance such as providing members with baptism gifts when their children were born, helping ill and destitute members, assisting the widows of members, paying hospital and funeral expenses, and carrying out other charitable works. Dürer's father was a goldsmith and after his death his widow, with no guilds to assist her, was left destitute and she moved into the Dürer household.

In Dürer's city, every space is designated and the areas between the buildings are significant enough for the streets to be light and airy, and the buildings were of sufficient size for the artisans to practise their trades. The layout of the trades is logical and enhancing to each profession - a city that would have enabled ideal working and living conditions for the artisans. Within this city their status is assured. In contrast to this city where everyone's position is defined, Dürer does not describe the palace precinct except to indicate its magnificence and state that it would be built according to the teachings of the Roman architectural theorist Vitruvius.

This city and its fortifications would have been very expensive to construct, even for a powerful and wealthy ruler. The fortifications span out from the city 2,098 feet in each direction from the other city walls. There are a series of walls, and lined and unlined ditches. On these ditches some of the industry such as butchery is conducted, 2,000 horses are housed, and there are huts and taverns available for the use of the soldiers. Horse-drawn mills and windmills are placed upon the unlined ditches and throughout different levels of fortifications are bastions and casements for the artillery. However, Dürer urged the powerful king to compare the cost of such a useful, solid fortification with the construction of the pyramids that had no community use. He also counsels the king to utilise his resources, to reveal himself as a socially responsible ruler. He claimed

The lords have many poor people whom they must feed by giving them alms; if they are paid a daily wage for their work, they will have no need to beg and are thus less likely to be moved to revolt. It is also better for a lord to spend a great deal of money on building in order to remain the ruler than to be conquered by his enemy in a battle and driven out of his land, as any person of low intelligence can easily understand. ${ }^{61}$

This is the action of a benevolent and prudent king. Dürer dedicated the book to Lord Ferdinand, King of Hungary and Bohemia who fortified many

\footnotetext{
${ }^{60}$ Strauss, p. 97.

${ }^{61}$ Dürer, Etliche Unterricht, sig. Ai.
} 
cities and towns after the peasants' revolt of $1525 .^{62}$ Revolt was a concern of Dürer's following the anti-tithe rebellions which erupted throughout southern Germany in the summer months of 1524. Some of the most significant opposition to the payment of tithes occurred at Forchheim, a village north of Nuremberg, on 26 May 1524, but the discontent did not remain outside of Nuremberg. The rebellion was soon supported within the town by tradesmen who attended rallies in the heart of the city. ${ }^{63}$ In the spring and early summer of 1525, the peasants throughout southern Germany rose in revolt. In both cases, anti-tithe rebellion and the peasants' revolt, Nuremberg was threatened. ${ }^{64}$ Groups of peasants carrying 'fire and swords' through the villages and towns, rioted and committed acts of iconoclasm against the images and statues they felt were idolatrous. ${ }^{65}$ It was in this year that Dürer began to write his book on fortification.

The British Library holds a manuscript with the text and diagrams for Etliche Unterricht. ${ }^{66}$ There are few corrections in the text, and the diagrams also show very little change to the finished product. The plans which are explained in the text are alphabetically mapped to the plans, however the plans supplied by Dürer are missing many of the letters and some of the geometry which is described in the text. ${ }^{67}$ The directions for the fortifications and the plans do seem to have been written in haste. This is not to say that the designs and architecture were ill-conceived, but there does appear to have been some urgency in the book's production. Perhaps this urgency was stimulated by the ongoing political and military problems of the time.

Both architecture and the development and status of the artisans were important to Dürer. In many ways, Etliche Unterricht addresses military architecture and the living conditions of artisans. The haste in which it was written leaves both issues incomplete, but not without lasting influence.

62 Thomas F. Sea, 'The German Princes' Responses to the Peasants' Revolt of 1525', Central European History 40 (2007), 219-40.

${ }^{63}$ Lawrence P. Buck, 'Opposition to Tithes in the Peasants' Revolt: A Case Study of Nuremberg in 1524', Sixteenth Century Journal, 4.2 (1973), 11-22 (pp. 17-18).

${ }^{64}$ Buck, p. 12.

65 Tom Scott, The Early Reformation in Germany: Between Secular Impact and Radical Vision (Farnham: Ashgate, 2013), pp. 12-13.

${ }^{66}$ BL, MS Sloane 5229, pp. 2-49.

${ }^{67}$ For examples, see Dürer, Etliche Unterricht, sigs Aii, Bi, Biii, Ciii. All of the letters are missing from the plan on sig. Cv. 


\section{Dürer's Architecture and the Influence of his Ideal City}

Although Dürer was strongly influenced by the works of Euclid and Vitruvius - he retained the translations of some of their texts and he reworked examples of their work in his notebooks - despite this influence, there is some similarity between his ideal city and that of contemporary architectural thought, particularly in his urban plan. Alberti's ' INU printed architectural book - had been completed by the 1450s but was not

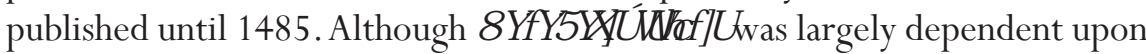
manuscripts of Vitruvius, Alberti did contribute to the concept of urban planning. Alberti's ideal city was planned within concentric circular rings of walls, but instead of the more traditional concept of the more prosperous citizens' dwellings being in the centre of the city, he placed them in the outer ring, his justification being that the wealthy needed more room. In the centre of the city were the artisan shops and stores around the forum. Alberti locates the goldsmiths, bankers, and decorators near the forum while the spice merchants, tailors, and respectable crafts are 'a little way off'. Alberti does not, though, give any details of the plans for these artisans' houses or shops. He makes clear locations for the houses of the trades, merchants, nobles, soldiers, and religion. Any trades that are dirty or cause pollution are put downwind of the other occupants. ${ }^{68}$

Alberti's urban plan also influenced Filarete. His architectural thesis was written between 1461 and 1464 and although it was popular it remained in manuscript form and was not published until the nineteenth century. ${ }^{69}$ Like Alberti, he proposes a circular city. The centre of the city was where the more substantial buildings were placed. He specifies a clearer overall plan for housing and the trades but without details of the houses themselves. While the main Plaza contains the government buildings, the guild house, and churches, there was a section of the urban plan for the more prosperous citizen. The services are dispersed in several neighbourhoods. As in Dürer's plan, the guilds are concentrated in areas specific to them: wool merchants, weavers and dyers, for instance, are together in one place, while the wheelwrights, coopers, rope makers, and shipwrights are in another. ${ }^{70}$

Francesco di Giorgio's thesis offers a very strict hierarchy of classes and dwellings in his Trattato di capitalize, Ingegneria e Arte Militare, which

${ }^{68}$ Leo Battista Alberti, On the Art of Building in Ten Books, trans. Joseph Rykwert, Neil Leach, and Robert Tavernor (Cambridge, MA: MIT, 1988), Book 5.

${ }^{69}$ John R. Spencer, 'Introduction', in Filarete's Treatise on Architecture, trans. and intro. John R. Spencer (New Haven, CT: Yale University Press, 1965), p. xvii.

${ }^{70}$ Filarete's Treatise on Architecture, Book 6. 


\section{Tessa Morrison}

was completed in 1482. It also remained in manuscript form and was not published until the nineteenth century. ${ }^{71}$ In Book Three, there is a plan for an ideal city with a star-shaped polygonal geometric structure where the city is planned around the centre and is given a strict urban hierarchy. Unlike Filarete and Alberti, Francesco provides plans for the buildings and instead of placing complementary guilds in the same area, he assigns the spice merchants, tailors, and the silk guilds to the most frequented streets, and the leather makers, armourers, and dyers to the peripheries of the city. In this way, he considers the location and conduct of the trade rather than the processes associated with it.

These three architectural theses were influential from the end of the fifteenth and into the nineteenth century. All three authors proposed an urban design which considered the placements of trade and industry, and while their architectural structure is significantly different from Dürer's, the urban layout in terms of the clustering of the guilds or classes has similarities. Dürer's hierarchy groupings are very rigidly laid out and Francesco, Filarete, and Alberti did not plan their hierarchies with such detail. How aware Dürer was of these three authors is difficult to verify since all three theses were written in Latin and in his surviving notebooks there are no translations or notes on them. In Underweysung der Messung, however, Dürer comes up with solutions for doubling a cube that are similar to Alberti's system. Also, in De Symmetria, instead of using fractions for types of human proportions he uses units of measurement which are also similar to Alberti's system. ${ }^{72}$ Dürer may have become aware of many of Alberti's ideas which had circulated through handwritten copies among his humanist friends. ${ }^{73}$ Dürer commented on architecture in his notes and in his designed buildings. There is a surviving architectural plan from 1505 that consists of elevations and floor plans for each floor of a five-storey building. ${ }^{74}$ In manuscripts held at the British Library are his copies of his translations of Vitruvius with many pages of drawings of the architectural details of Vitruvius's text. ${ }^{75}$ In Underweysung Der Messung, he shows several designs and specifications for columns. He

\footnotetext{
${ }^{71}$ Franceso di Giorgio Martini, Trattato di architettura civile e militare, ed. Cesare Saluzzo (Turin: Chirio e Mina, 1841).

72 David Price, 'Dürer's De Symmetria and Underweysung Der Messung', in De symmetria partium in rectis formis humanorum corporum (Nuremberg, 1532); Underweysung der Messung (Nuremberg, 1538), ed. Price, pp. 5-6.

${ }^{73}$ Hans Rupprich, 'Die kunsttheoretishen Schriften L. B. Albertis und ihre Nachwirkungen bei Albrecht Dürer', Schweizer Beitrage zur allgemeinen Geschichte, 18-19 (1960), 219-39.

${ }^{74}$ BL, MS Sloane 5229, pp. 167-71.

${ }^{75}$ For example, BL, MS Sloane 5229, pp. 140, 187; BL, MS Sloane 5230, pp. 65, 80, 93, 180, 188, 195-96.
} 
writes a comprehensive critique of the design of a replacement roof for a church in Nuremberg, and provides an alternative plan. ${ }^{76}$ His advice was sought on fortified cities such as Antwerp. William Bell Scott's biography of Dürer, published in 1869, suggests that additions to buildings in Nuremberg that Dürer had designed still existed in the mid-nineteenth century. ${ }^{77}$ In his journal in Antwerp in 1521, he recorded that he did a plan of the house for which he charged 10 florins for the physician of Lady Marguerite, King Charles's sister. ${ }^{78}$ The illustrations in Etliche Unterricht are skilled architectural plans, sections, and elevations that demonstrate a full understanding of architectural theory. In a Latin edition of his work of fortification published in Paris in 1535, its publisher and translator Christian Wechel styled Dürer as 'Painter and Architect' ${ }^{79}$ Although he revered Vitruvius and had a preference for the lower line of classical roofs, his designs still showed a strong Gothic influence. There is no doubt that he worked in some capacity as an architect for a significant number of years. Although the publication of Etliche Unterricht may have been rushed, the layout of the city was carefully considered and as an ideal city it did have subsequent influence.

Book Six of Sebastiano Serlio's Tutte L'opere D'architettura et Prospetiva is on domestic architecture in both the country and the city. However, unlike the rest of this manuscript, this section was not published until the twentieth century. ${ }^{80}$ Book Six is one of the most comprehensive treatments of housing from the Renaissance. Serlio provides plans and elevations, and every stratum is subdivided according to income from the lowest classes of poor artisans to the most wealthy and prosperous citizens. He also considers the placement of the classes: the stratification of Serlio's city plan of dwellings is based on the hierarchical structure of French society which was imposed by the monarchy and reinforced by early Renaissance architectural theorists. There are strong similarities with Dürer's urban layout. ${ }^{81}$ Serlio places the square in the centre of the town with the ruler's house in the middle and the urban plan stemming

${ }^{76}$ BL, MS Sloane 5229, pp. 165-66.

${ }^{77}$ William Bell Scott, Albert Durer: His Life and Works (London: Longmans, Green, 1869), p. 320

${ }^{78}$ Dürer, Memoirs of Journeys, p. 91.

${ }^{79}$ Albrecht Dürer, Pictoribus, fabris cerariis ac lignariis ... quatuor his suarum institutionum geometricarum libris, trans. Christian Wechel (Paris, 1535), frontispiece.

${ }^{80}$ Sebastiano Serlio on Domestic Architecture: Different Dwellings from the Meanest Hovel to the Most Ornate Palace, ed. Myra Nan Rosenfeld (New York: Architectural History Foundation, 1978).

81 James S. Ackerman and Myra Nan Rosenfeld, 'Social Stratification in Renaissance Urban Planning', in Urban Life in the Renaissance, eds Susan Zimmerman and Ronald F. E. Weissman (Newark: University of Delaware Press, 1989), pp. 21-49 (pp. 28-29). 


\section{Tessa Morrison}

from that central point in a highly hierarchical and stratified plan. Dürer influenced the plan of one of the most significant utopian city designs.

In 1619, Johann Valentin Andreae published Christianopolis. ${ }^{82}$ In Christianopolis he described a Christian Commonwealth and the architecture of what he perceived to be a utopian city. It is a fortified city with triangular bastions on each corner (see Figure 4). For Andreae, the study of fortification was a science and a branch of mathematics. In Collectaneorum mathematicorum decades XI. Centum et decem tabulis aeneis exhibitce, published in 1614, he revealed a study of fortifications and he reproduced a plan of the 'perfect' fortification by Alsatian fortress architect, engineer, and cartographer, Daniel Speckle, as part of this study. ${ }^{83}$ He also constructed a preliminary plan of a small fortified complex which resembles Christianopolis (see Figure 5), ${ }^{84}$ followed by an analysis of the different alignments of triangular bastions. ${ }^{85}$ This plan does not resemble the perfect fortification of Speckle; rather its overall shape is more reminiscent of Albrecht Dürer's work on fortification Etliche Unterricht. The round bastions of Dürer have been replaced with the more modern triangular bastions but the similarity is striking. It is interesting that although the main authority for Andreae's study of fortifications rests on the account of Daniel Speckle, in his ideal city it is to Dürer's design that he turns. Eight massive towers reinforce the fortifications, plus there are sixteen smaller towers on the corners of the inner rows, and in the middle of the city there is a citadel which is impregnable. Outside of the walls, the moat is 50 feet wide which not only suffices as extra fortification but in peace time is full of fish and does not lie idle. ${ }^{86}$

The layout of the city consists of four rows that encompassed the city: the first row is the industrial area; rows two and three are the domestic quarters which housed the craftsmen and their workshops; and row four is the College which surrounded the central square containing the Temple. Although the overall plan is similar to Dürer's, the greatest similarity is in Andreae's industrial and domestic areas and in their layout. The first row that encompasses the city contains the storerooms and industry. Andreae organised this into four sectors to separate the different industries and each of these four sectors is divided by the main, intersecting road into two parts. To the east, is the centre for farming activity: on one side of the road are

82 Johann Valentin Andreae, Christianopolis, trans. and intro. Edward H. Thompson (Dordrecht: Kluwer, 1999).

${ }^{83}$ Joannis Valentin Andreae, Collectaneorum mathematicorum decades XI. Centum et decem tabulis aeneis exhibitae (Tubingen: Cellius, 1614), Plate 89.

${ }^{84}$ Andreae, Collectaneorum mathematicorum, Plate 77.

85 Andreae, Collectaneorum mathematicorum, Plates 85-88.

${ }^{86}$ Andreae, Christianopolis, pp. 161-62. 
grain, pulses, and vegetables, while on the other is the rearing of animals and birds. To the south, are the farm buildings on one side of the road that include seven buildings for milling and another seven for baking, while on the other side of the road are the buildings that deal with fish, meat, and other provisions. On the north side are the buildings for butchery and provisions, and here also are buildings for slaughtering, the preparation of meats, and the kitchens. There is provision for storage of products such as butter, suet, lard, and wax. Finally, on the west side are workshops for stamping, smelting, casting, and moulding with metals, while on the other side of the road are workshops for the manufacture of salt, glass, bricks, earthenware, and all things that require heating. ${ }^{87}$

In the domestic quarters, the craftsmen are arranged on the four sides in terms of material they use: metal, stone, wood, or textiles. In this distribution those with the greatest skill belong to the inner row and those with lesser skills are consigned to the outer row. For the metal side, the clockmaker belongs to the inner row and the saw-maker to the outer row. Andreae did not specify on which side each material would be located, but designated which crafts belonged to the inner and outer rows; on the timber side, organ makers belong to the inner row and box makers the outer, while on the stone side, the sculptors occupy the inner row and the stone makers the outer. ${ }^{88}$ As with Dürer's plan, there remains a hierarchical structure to the trades that are arranged in the same pattern of commodity and convenience, and provide a quality of life for the artisan.

\section{Conclusion}

Dürer's final letter to Pirckheimer from his first trip to Venice in 1505-06 stated that 'Here (in Venice) I am a gentleman, at home a parasite' ${ }^{89}$ implying a reluctance to return to Nuremberg. Yet prior to the writing of this letter, he had turned down an offer from the Doge of Venice to enter the service of the nation city-state, for which he would have been paid 200 ducats per year if he lived and worked in Venice. ${ }^{90}$ The council of Antwerp in 1520 had also offered him 300 florins a year and a fair mansion if he remained in Antwerp. ${ }^{91}$ However, he always returned to Nuremberg and continued his work not only

${ }^{87}$ Andreae, Christianopolis, pp. 163-70.

${ }^{88}$ Andreae, Christianopolis, p. 171. Andreae does not give an example for the textile section.

${ }^{89}$ Dürer, Memoirs of Journeys, p. 27.

90 Scott, Albert Durer, p. 178; Conway, Literary Remains, p. 59.

${ }^{91}$ Scott, p. 178. 
in painting and printmaking, but also producing a body of work that would educate and better prepare young German artisans.

Of Dürer's three books, Etliche Unterricht superficially appears to be in contrast with his books on measurements and human proportion. Although it seems to be a work written in haste, its content was not conceived in haste. His architectural study went back to at least 1500 and he later practised as an architect. The ideal city offered two advantages: fortification and maintenance of the city to the ruler; and improved lifestyle and conditions to the artisans who would occupy the city. Given the peasants' revolt and the unsettled times, the need for the former could explain the haste of the text's publication, but the latter can be seen in the context of Dürer's desire and long-term plans to improve the skills, lifestyle, and status of German artisans.

Despite the influence of the Renaissance architectural theorists Alberti, Filarete, Francesco, Serlio, and Dürer, and with the exception of Fuggerei, the segregation of living quarters by either trade or classes was not accepted in urban planning. In fact, the opposite dominated housing practices, as there had been a concentration on mixed use to ensure a variety of goods and services on every street. ${ }^{92}$

Fuggerei, Augsburg, was a significant housing development for the poor that improved the lifestyle of labourers and poor craftsman and it not only housed the craftsmen but also provided the workshops to enable them to practise their trades. The relationship between the Fugger family and Dürer was important throughout Dürer's working life and in his capacity as an architect, Dürer would have had an interest in the creation of an ideal city for artisans. Although there is no evidence of his involvement in the building or design of Fuggerei he would have been well aware of its construction since he visited Augsburg many times while it was being built. It would also have attracted his attention as an educator who was interested in the status and wellbeing of young artisans. Dürer's city, though, was a on much larger scale and far more ambitious than Fuggerei.

His three books were published in the last few years of his life. While Underweysung der Messung and Vier Bücher von Menschlicher Proportion have been thoroughly examined and scrutinised over the last 500 years, Etliche Unterricht has had a great deal less consideration. There is no doubt that it is an incomplete study and this may have been because of the military imperative created by the peasants' revolt and the continuous fear of its reoccurrence. However, his concept of the ideal city represents a significant development in urban planning theories of the sixteenth century, and it was still considered ideal in the seventeenth century, influencing Andreae's Christianopolis.

\footnotetext{
${ }^{92}$ Ackerman and Rosenfeld, 'Social Stratification', p. 39.
} 
In Dürer's ideal city, the king would allow only useful people to live and in his plan the majority of the occupants were artisans - they were no longer parasites, but gentlemen.

The University of Newcastle, NSW 


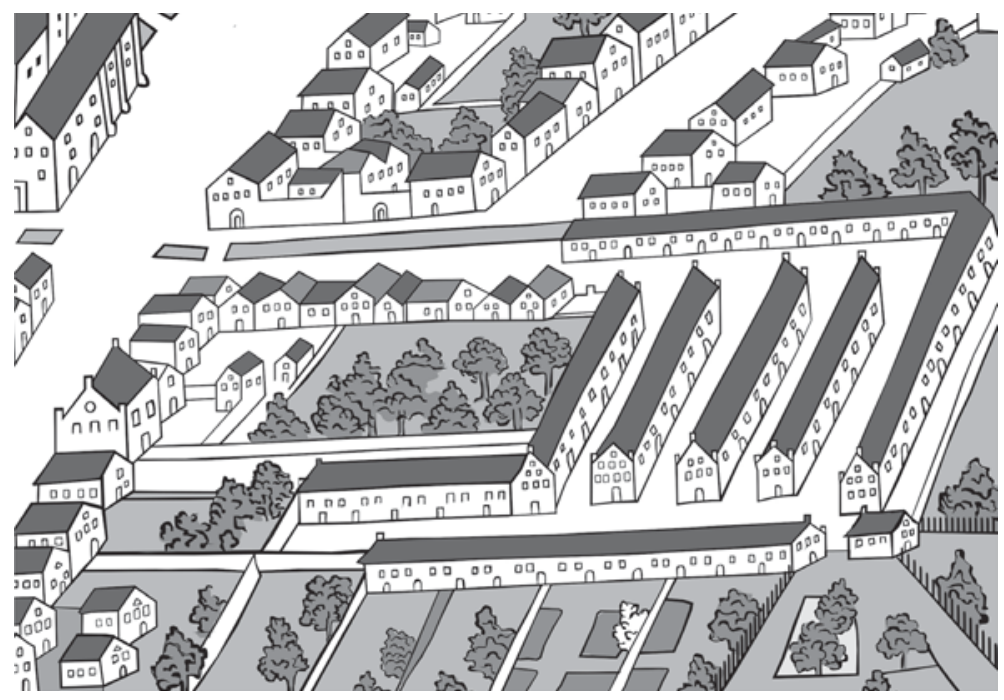

Figure 1

Joerg Sild's earliest sketch of Fuggerei, 1521.

Facsimile (drawn by the author) of Martin Kluger, The Fugger Dynasty: The German Medici in and around Augsburg (Augsburg: Context, 2008), p. 58.

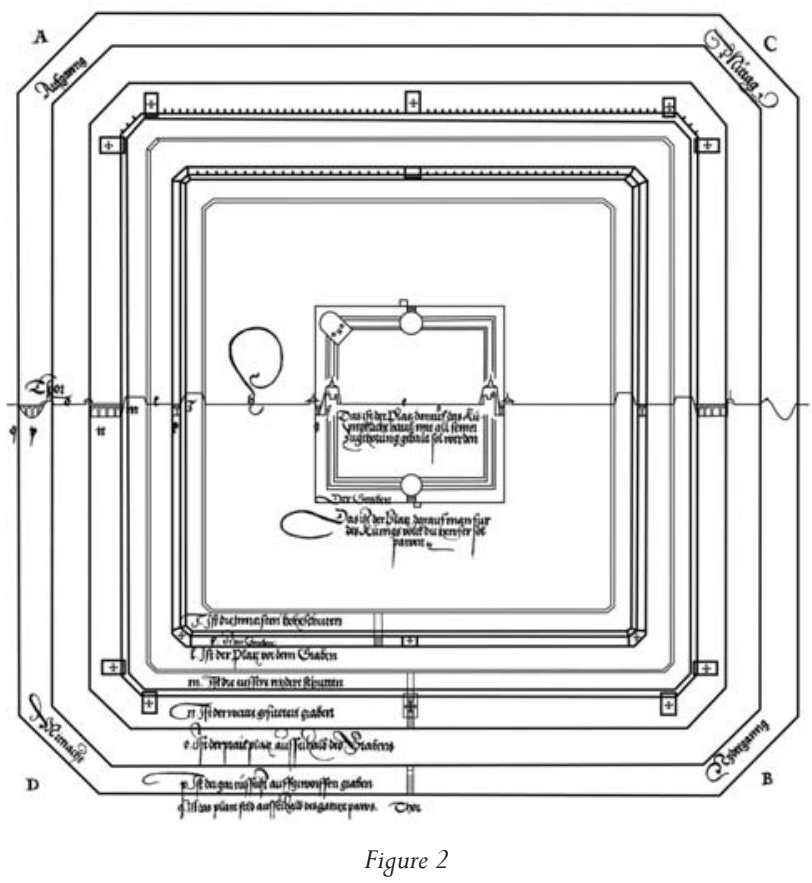

Dürer's plan of the ideal city's fortifications.

Facsimile (drawn by the author) of Albrecht Dürer, Etliche Unterricht, Zur Befestigung Der Städte, Schlösser Und Flecken (Nuremberg, 1527), sig. Diii. 


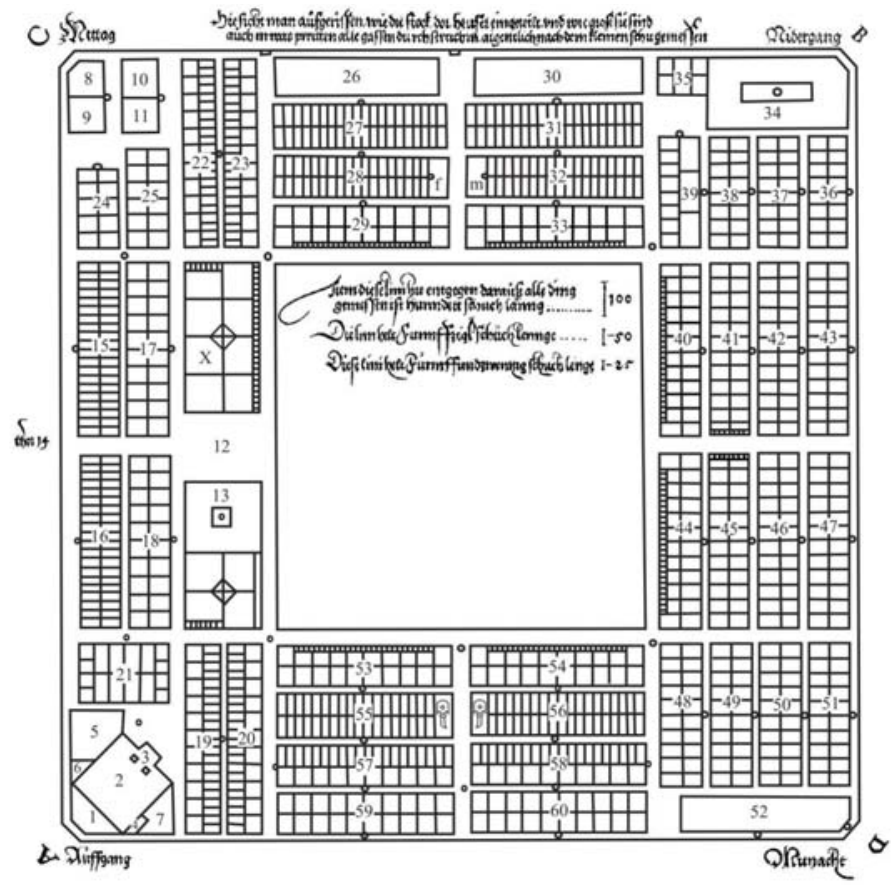

Figure 3

Dürer's plan of the ideal city.

Facsimile (drawn by the author) of Albrecht Dürer, Etliche Unterricht, Zur Befestigung der Städte, Schlösser und Flecken (Nuremberg, 1527), sig. Ei.

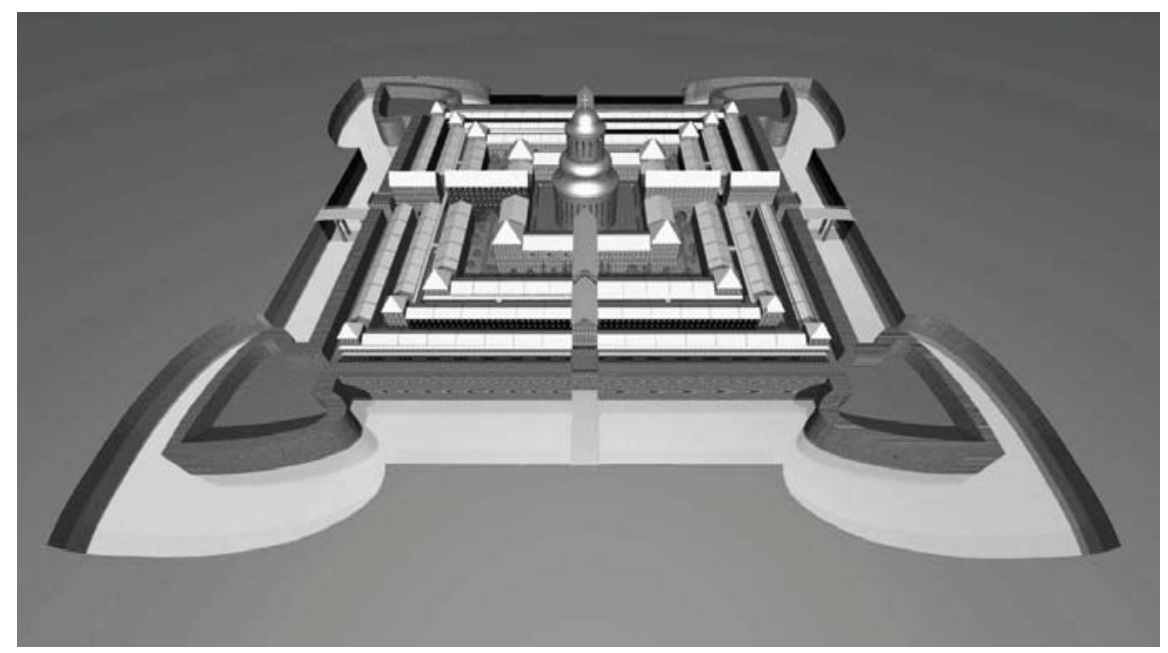

Figure 4

Reconstruction of Andreae's Christianopolis.

Modelled by the author from Johann Valentin Andreae, Christianopolis, trans. and intro. Edward H. Thompson (Dordrecht: Kluwer, 1999), p. 22. 


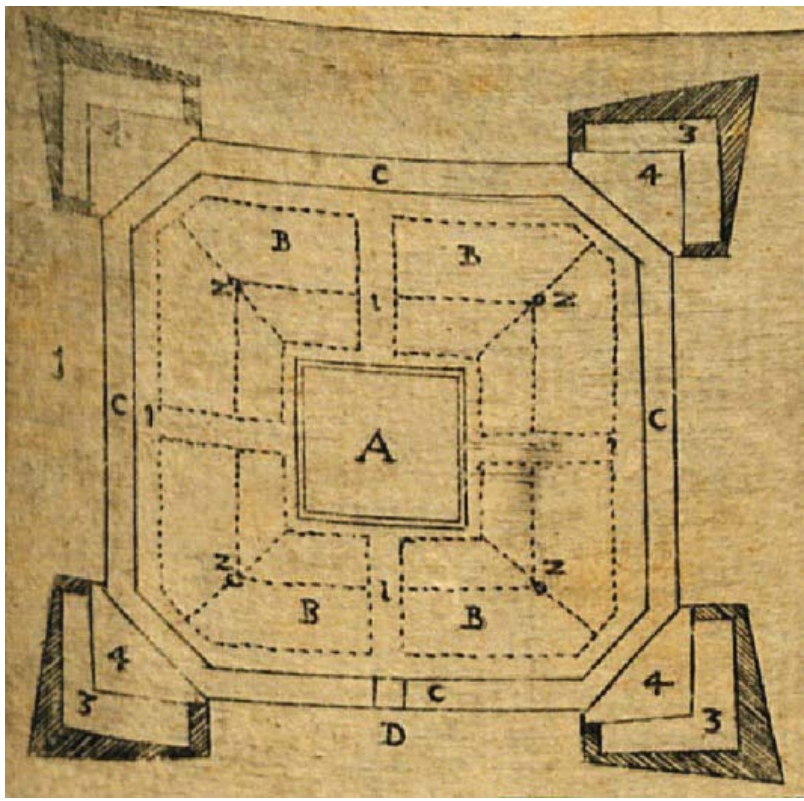

Figure 5

Andreae's plan for a small, fortified complex.

Source: Joannis Valentin Andreae, Collectaneorum mathematicorum decades XI. Centum et decem tabulis aeneis exhibitae (Tubingen: Cellius, 1614), Plate 77. Author's private collection. 
Copyright of Parergon is the property of Australian \& New Zealand Association for Medieval $\&$ Early Modern Studies and its content may not be copied or emailed to multiple sites or posted to a listserv without the copyright holder's express written permission. However, users may print, download, or email articles for individual use. 